\title{
CALENDAR OF ECONOMIC EVENTS JULY-SEPTEMBER 1982
}

Classification for calendar items:

(A) INDUSTRY -includes bids, mergers, commercial policy; (B) LABOUR AND PRICES-including strikes, claims, settlements, prices; (C) INTERNATIONAL-including policy developments overseas (Central bank discount rate changes), IMF, (monetary exchange rates) and trade, EC; (D) UNITED KINGDOM GENERAL-including domestic policy, interest rate changes and Cmnd papers.

July

(B)

(D)

1 Total cuts petrol price by $5 \mathrm{p}$ a gallon to $172.8 \mathrm{p}$.

1 The Defence Secretary announces multimillion defence purchasing programme which will both replace equipment lost during the Falklands conflict and add to Britain's conventional armoury: approval for the type 23 frigate; an extra type 22 frigate at a cost of $£ 135$ million and a major new purchasing programme for helicopters which will include nine Sea Kings, three Lynx and up to five Gazelles and fourteen Sea Harriers each costing $£ 8$ million from British Aerospace.

(A) $\quad 1$ ICI to buy the loss-making dyes and pigments business of the French-based Produits Chimiques Ugine Kuhlmann for $£ 50$ million.

1 Britain's 1.7 million engineering workers to lodge claim of about 10 per cent in negotiations and to raise the pay of unskilled workers by 14 per cent, narrowing the differential between skilled and unskilled to 20 per cent.

2 Mr Roy Jenkins wins election for the leadership of the Social Democratic Party.

2 GEC-Hitachi to make more than 800 of the 1,900 workers at its South Wales plant redundant in the next five months.

4 Control of the commodity business of Guinness Peat to be sold to a group of managers and investors in a deal worth $£ 11$ million.

5 British Telecom announces package of proposed tariff changes which would increase subscribers' bills by an average of 3.3 per cent from 1 November.

11 OPEC conference in Vienna suspended without agreement. Failure of the talks resulted from: Iran's determination to increase its exports of crude to 3 million barrels a day and its refusal to align its prices with the official prices of other members; Libya's exceeding the 800,000 barrels a day quota agreed in March and the refusal by Algeria, Libya and Nigeria to agree to a rise in the differential charged for their oil. The meeting will be resumed in late August.

(A) 13 Dunlop Holdings announces agreement to sell its remaining industrial interests in Malaysia for $£ 73$ million to Pegi Malaysia Berhad.

(A) 12 Babcock Power, boiler-making division of Babcock International, wins a £100 million contract for four coal-fired boilers for a Zimbabwe power station.

(B) 12 British Airways confirms its intentions to reduce its workforce by 7,000 from the present level of 42,000 by 31 March next year. This follows redundancies of about 9,000 over the past year achieved through voluntary severence, and will mean 23,000 staff have left the airline over the past three years.

(D) 13 UK clearing banks reduce base rate from 12 ? to 12 per cent.
(D)
13 The TUC and the Labour Party announce a joint programme for 'social and economic reconstruction' in a TUC-Labour Party Liaison Committee document, Economic planning and industrial democracy proposing co-determination of the economy between government, unions and employers at national level and co-determination of corporate policy by employers and unions at company level.

14 Abbey National Building Society launches new 'extra interest' savings scheme next month. Investors will have to maintain a minimum balance of $£ 100$ and a seven day notice of withdrawal will be required with no penalty.

15 British Shipbuilders announces plans to cut its ship repair workforce by 1,500 in an attempt to stem losses of $£ 1$ million a month.

14 The Royal College of Nursing to ballot its members on the government's pay offer of $7 \frac{1}{2}$ per cent.

18 ASLEF agree to accept Trades Union Congress formula to call off its two-week old strike from midnight and to recommend to its conference acceptance of the disputed issue of flexible rostering.

18 Members of the 12 TUC-affiliated health unions-representing more than 600,000 workers-to start three-day strike action over their 12 per cent pay claim.

19 US Federal Reserve Board cuts discount rate from 12 to $11 \frac{1}{2}$ per cent.

20 British Petroleum to export North Sea oil to Japan under a contract worth $£ \mathbf{3 2 2}$ million with Mitsubishi Oil.

22 Aetna Life and Casualty, US insurance company, to pay $£ 66.1$ million for a 40 per cent interest in Samuel Montagu, the London merchant bank.

22 The government is to cut substantially its grant to local councils in 1983-4, for the second consecutive year. The money available to councils for spending on wages and services is to be cut by 2 per cent in real terms. The percentage of current expenditure funded by the Government will be cut from 56.1 per cent this year to between 53 and 54 per cent next year: the total available for exchequer grant in 1983-4 will be $£ 11.8$ billion; a sum of $£ 900$ million will be added to the total current expenditure target for councils next year and no new penalties for the $£ 1.4$ billion overshoot of targets this year but tougher penalties will be enforced next year.

26 Two large US banks cut prime rates from 16 to $15 \frac{1}{2}$ per cent.

$26 \mathrm{BP}$ and Esso reintroduce subsidies to dealers which will mean a cut in pump prices of $5 \mathrm{p}$ a gallon bringing the average price to $172.8 \mathrm{p}$ a gallon.

27 All government hire purchase controls on cars and other consumer goods have been abolished with effect from today. 
(C) 30 US Federal Reserve Board cuts discount rate from $11 \frac{1}{2}$ to 11 per cent.

(D) 30 Clearing banks cut base rate from 12 to $11 \frac{1}{2}$ per cent.

August

(B) 2 National strike by Sealink seamen over dispute of 450 seamen on Sealink's loss-making route between Harwich and the Hook of Holland, who have been asked to accept wage cuts and change working practices.

(C) 2 US banks cut prime rate from $15 \frac{1}{2}$ to 15 per cent.

(B) 5 Building Societies cut mortgage rate from 131 to 12 per cent.

(D) 5 National Westminster Bank cuts personal loan interest rate to 17.7 per cent with effect from today.

(B) 6 Shell to increase petrol prices by $8 \mathrm{p}$ a gallon following its decision to cut the subsidy paid to retailers.

(D) 9 Barclays Bank and Midland Bank reduce mortgage rates from 14 to $12 \frac{1}{2}$ per cent.

(B) 6 Police force awarded 10.3 per cent pay increase but an imposition of a 4 per cent increase in pension contributions reduces the value of the award to 5.6 per cent.

(A) 11 BP and London and Scottish Marine Oil, a UK independent oil company, jointly pay $£ 159$ million for the international exploration and production interests of Dome Petroleum of Canada.

(A) 11 Chrysler of the US and Perkins Engines, to set up a $£ 174.4$ million joint venture in Ontario to build diesel engines for cars and light trucks with financial backing from the Canadian government and the government of Ontario.

(B) 11 The British Steel Corporation announces closures of three plants with loss of 1,122 jobs.

(D) 11 Williams and Glyn's reduce mortgage rates from $13 \frac{3}{4}$ to $12 t$ per cent.

(A) 12 Dan Air to buy two of British Aerospace's BAe 146 four-engined, short-range jet airliners for $£ 15$ million.

(C) 13 US Federal Reserve Board cuts discount rate from 11 to $10 \frac{1}{2}$ per cent and several major banks cut prime rates from 15 to $14 \frac{1}{2}$ per cent.

(D) 17 Clearing banks cut base rate from $11 \frac{1}{2}$ to 11 per cent.

(B) 17 Oil companies to raise petrol prices to $180 \mathrm{p}$ a gallon.

(A) 23 ICL wins contract worth $£ 20$ million to supply 18,000 DRS 20 desktop terminals for the computerisation of the Inland Revenue's Pay As You Earn operation.

(B) 23 White collar staff in the water industry accept $7 \frac{1}{2}$ per cent pay rise backdated to 1 July.

(C) 26 US Federal Reserve Board cuts discount rate from $10 \frac{1}{2}$ to 10 per cent.

(B) 26 Royal College of Nursing reject government's offer of 7.5 per cent pay award (see 14 July).

(D) 27 Clearing banks cut base rate from 11 to $10 \frac{1}{2}$ per cent.

(B) 27 Vauxhall manual workers reject $7 \Varangle$ per cent pay offer.

(C) 29 The BIS announces that, as part of total facilities amounting to $\$ 1,850$ million which are being made available to the Banco de Mexico in co-operation with the US monetary authorities, it has agreed to grant the Banco de Mexico a credit of $\$ 925$ million with the support of the central banks of the other Group of Ten countries, Switzerland and Spain. The agree-

ment provides for drawings on the facility in three tranches in line with progress towards agreement between the Mexican government and the IMF on an economic stabilisation programme which will enable Mexico to qualify for drawings under the IMF's extended facility.

(B) 31 British Telecom postpones proposed increase in telephone charges until next April (see 5 July).

\section{September}

(B)
3 Process and clerical workers at the British Sugar Corporation accept 8-91 per cent pay offer.

7 The government and electricity authorities give permission for the construction of a $£ 6.2$ million power-generating wind turbine to be installed in the Orkney Islands by the Wind Energy Group.

7 Two companies in the GEC-Marconi group have won contracts worth more than $£ 30$ million from the Ministry of Defence.

8 National Westminster Bank and Midland Bank in a joint move to create a cash dispenser network in Europe making their cash dispensers available to each other's customers from next spring.

9 BOC Group issues a $£ 100$ million long-term fixed interest bond repayable in 35 years at 121 per cent.

10 BP to increase petrol prices to an average $176 \mathrm{p}$ per gallon from 13 September as a result of a $5 p$ cut in the subsidy to distributors.

12 British Rail's arbitration tribunal to recommend pay increases of 6 per cent for BR's 177,000 workers, tied to improved productivity. The increase would be paid only from the date of publication or from agreements to the Tribunal's findings, which would reduce the costs to BR by 3.5 per cent over the year from the settlement date last April.

13 ICL, UK computer manufacturer, wins $£ 15.8$ million contract to supply small computer systems to New York State Department of Social Services.

16 The French government announces that it is seeking a $\$ 4$ billion loan in the Euromarket to defend the French franc. Interest on the loan, the largest ever syndicated on the Euromarket for a government, is to be set at half a point over LIBOR.

22 TUC day of action in support of the health service workers' pay campaign.

22 Leaders call for first national strike by water and sewerage workers on 18 October in pursuit of a 15 per cent pay claim.

23 Mrs Shirley Williams elected as President of the Social Democratic Party.

23 Government announces auction of fifteen blocks in the central sector of the North Sea by cash tender as part of the eighth round of off shore licensing. Closing date for receipt of applications is 17 January 1983.

24 F. W. Woolworth to close 336 Woolco discount stores in the US in a move to restructure the money-losing operation.

24 BNOC to keep the price of North Sea oil unchanged at $\$ 33.50$ per barrel for the fourth quarter.

26 Plessey agrees to buy a substantial part of Stromberg-Carlson a subsidiary of United Technologies, a US telecommunications company for $£ 33$ million.

28 Bankers Trust cuts prime rate from $14 \frac{1}{2}$ to 13 per cent. 


\section{STATISTICAL APPENDIX TABLES}

Page

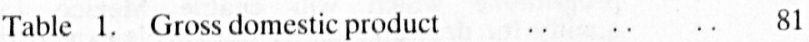

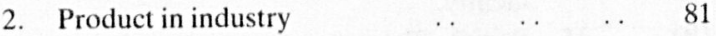

3. Production of coal, oil, steel and cars $\quad$. $\quad 82$

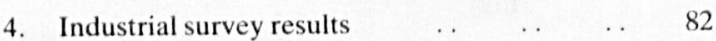

$\begin{array}{lllllll}\text { 5. Orders } & \text { O } & \ldots & \ldots & \ldots & \ldots & 82\end{array}$

6. The labour market; productivity $\quad \ldots \quad \ldots 33$

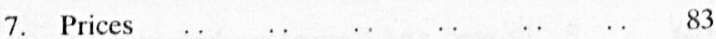

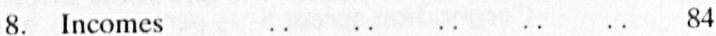

9. Consumers' expenditure; retail sales $\quad \ldots \quad 84$

10. Fixed investment $\quad$.

11. Changes in the volume of stocks $\quad$. . $\quad$. $\quad 85$

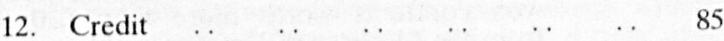

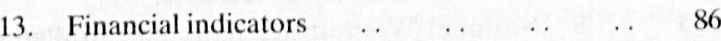

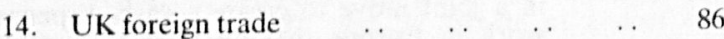

Table 15. UK imports by commodity, and measures of competitiveness

16. UK exports, by commodity and area

17. UK balance of payments

18. Exchange rates (trade conversion factors)

19. Prices in industrial countries and OECD

20. Earnings and wage costs in industrial countries

21. Industrial production and unemployment in industrial countries and $\mathrm{OECD}$

22. Gross product and productivity in industrial countries and OECD

23. World trade

24. Trade of industrial countries

25. Exports of manufactures and export prices ..

26. Commodity prices
Page

\section{STATISTICAL APPENDIX: DEFINITIONS AND EXPLANATIONS}

\section{GENERAL NOTES}

Country groups

Unless otherwise stated, country groups are constituted as follows:

OECD: North America, EC, EFTA, Australia, Japan, Spain and Turkey.

North America: US and Canada.

EC: Belgium-Luxembourg, Denmark, France, West Germany, Greece, Irish Republic, Italy, Netherlands and UK.

(Note: Germany in table headings refers to West Germany throughout.)

EFTA: Austria, Finland, Iceland, Norway, Portugal, Sweden and Switzerland.

(Although it is a member of the OECD, comparable figures are not always available for New Zealand - it is, therefore, for the purpose of these tables, with the exception of table 22 , treated as a non-member.)

Non-OECD countries: Oil exporters, centrally planned, other developed and non-oil developing countries.

Oil exporters: Algeria, Bahrain, Brunei, Ecuador, Gabon, Indonesia, Iran, Iraq, Kuwait, Libya, Nigeria, Oman, Qatar, Saudi Arabia, Trinidad and Tobago, United Arab Emirates and Venezuela.

Centrally planned: Albania, Bulgaria, China, Czechoslovakia, East Germany, Hungary, Mongolia, North Korea, North Vietnam, Poland, Rumania and the Union of Soviet Socialist Republics.

Other developed: Malta, New Zealand, South Africa and Yugoslavia.

Non-oil developing: All non-OECD countries not included elsewhere, but excluding Taiwan.

Taiwan is excluded from table 23 because data for it are no longer published by the IMF.

$U K=$ United Kingdom; $G B=$ Great Britain.

Valuation of imports and exports

Imports are valued c.i.f. and exports and re-exports f.o.b., unless otherwise stated.

Full definitions were given in the National Institute Economic Review No. 99, February 1982, pages 98-99.
Seasonal adjustments

A number of monthly and quarterly series have been adjusted to eliminate the estimated normal seasonal variations. All seasonally adjusted series must be regarded as containing a margin of uncertainty, depending, in particular, on the extent to which seasonal variations can be shown to have been regular in the past.

Except where otherwise stated in the following definitions the seasonal adjustments are those applied by the official producers of the series.

Sources:

The main sources and abbreviations in the following tables are:

BB:

BCR:

BCR:
BEQB:

BP: $\quad$ United Kingdom Balance of Payments (HMSO, annually)

CIRM: Congiuntura Italiana, Rassegna Mensile (Istituto Nazionale per lo Studio della Congiuntura)

CP: $\quad O E C D$ press release: Latest trends in consumer prices (monthly)

CSO: UK Central Statistical Office

CW: Commodity Weekly

DEG: Department of Employment Gazette (HMSO, monthly)

DOE: Department of the Environment press release

EC: European Communities

EO: $\quad$ Economic Outlook (OECD, semi-annually)

ES: Economic Surveys (OECD)

ET: Economic Trends (HMSO, monthly)

FS: $\quad$ Financial Statistics (HMSO, monthly)

FT: $\quad$ Financial Times

IFS: International Financial Statistics (International Monetary Fund, monthly)

IIA: Indicators of Industrial Activity (OECD, quarterly)

IRS: Informations Rapides Series $S$ (Institut Nationale de la Statistique et des Etudes Economiques)

MDS: $\quad$ Monthly Digest of Statistics (HMSO)

MEI: $\quad$ Main Economic Indicators (OECD, monthly)

MRETS: Monthly Review of External Trade Statistics (Departments of Industry and Trade - common services)

OECD: Organisation for Economic Co-operation and Develop-

ONAB: $\quad$ ment $\quad$ Narterly National Accounts Bulletin (OECD)

ONAB: Quarterly National Accounts Bulletin (OECD)

$\begin{array}{ll}\text { RC: } & \text { Raw Cotton Report (Liverpool Cotton Association) } \\ \text { SBR: } & \text { Statistische Beihefte, Reihe } 4 \text { (Deutsche Bundesbank) }\end{array}$

SCB: Survey of Current Business (US Dept of Commerce, monthly)

SFTA: Statistics of Foreign Trade, Series A (OECD, monthly)

SFTB: Statistics of Foreign Trade, Series B (OECD, annually)

SSS: Social Security Statistics (DHSS, annually)

UNCTAD: United Nations Conference for Trade and Development

UNMBS: UN Monthly Bulletin of Statistics

Statistics derived from these publications are not described in detail. For more information, reference should be made either to these publications or to their explanatory supplements. Publications are referred to by their current titles. 